\title{
PERAN KONSEP DIRI, MINAT DAN KEBIASAAN BELAJAR PESERTA DIDIK TERHADAP PRESTASI BELAJAR FISIKA
}

\author{
PURNI MUNAH HARTUTI \\ purniibunyahanum@yahoo.co.id \\ Program Studi Teknik Informatika, Fakultas Teknik, Matematika \& IPA \\ Universitas Indraprasta PGRI
}

\begin{abstract}
Abstrak. Tujuan dari penelitian ini adalah untuk menganalisis peran konsep diri, minat dan kebiasaan belajar peserta didik terhadap prestasi belajar fisika. Metode penelitian yang digunakan adalah metode survey dengan menggunakan teknik korelasi dan regresi ganda dengan bantuan program SPSS versi 17.0 Setelah penulis menganalisis semua variabel dapat disimpulkan bahwa; konsep diri, minat dan kebiasaan belajar peserta didik secara bersama-sama memberikan peran terhadap prestasi belajar Fisika sebesar $89,8 \%$. Artinya $89,8 \%$ prestasi belajar Fisika dapat dijelaskan oleh variabel konsep diri peserta didik, minat belajar peserta didik dan kebiasaan belajar peserta didik secara bersama-sama. Dengan demikian guru dalam satuan pendidikan hendaknya dapat menanamkan konsep diri pada peserta didiknya dan meningkatkan cara pengajaran yang baik untuk menarik minat belajar peserta didiknya serta dapat memberikan dorongan pada peserta didiknya untuk melakukan kebiasaan belajar yang baik.
\end{abstract}

Kata Kunci: konsep diri, minat belajar, kebiasaan belajar dan prestasi belajar fisika

\begin{abstract}
The objective of this reseacrh is to analyze the effect of self-concept, interest and habbits of student study on the learning achievement of physics. The methode of this research is using survey with correlation and multiple regression used SPSS version 17.0. The finding of this reseacrh are self concept, interest and habbits of student study influenced together on the learning achievement of physics for $89,8 \%$. It means $89,8 \%$ the learning achievement of physics described by Self concept student, Interest of student study and habbits of student study influenced together. Teachers in education field should be able to improve self concept to their students and improve the way how to teach in good way to get the learning interest of their student. Also they can give support to their students to do good learning habit.
\end{abstract}

Keywords: self concept, interest, habbits of student study and learning achievment of physics

\section{PENDAHULUAN}

Pendidikan di Indonesia masih terbilang rendah dan belum berhasil optimal, terlebih lagi untuk pembelajaran Fisika. Masalah utama dalam pendidikan di Indonesia adalah rendahnya prestasi belajar peserta didik di sekolah. Dalam konteks pendidikan Fisika, sebagai contoh, prestasi belajar dimaksud tidak hanya pada aspek kemampuan mengerti Fisika sebagai Ilmu Pengetahuan Alam atau cognitive tetapi juga aspek sikap atau attitude terhadap Fisika. Selanjutnya untuk aspek sikap peserta didik terhadap Fisika di sekolah, dapat diketahui tidak hanya dari beberapa publikasi penelitian, tetapi dari opini peserta didik di sekolah bahwa mereka tidak suka atau bahkan takut pada beberapa pelajaran khususnya pelajaran Fisika. Di sisi lain semua pihak menyadari bahwa Fisika merupakan Ilmu Pengetahuan Alam yang banyak memerlukan pemahaman konsep yang harus dipelajari oleh setiap peserta didik. Di samping pelajaran bahasa Indonesia, Bahasa Inggris, Matematika dan Ilmu Pengetahuan Sosial, Fisika merupakan pelajaran penting 
yang harus diajarkan pada setiap jenjang pendidikan. Fisika merupakan pelajaran yang memberikan pengetahuan tentang alam semesta untuk berlatih berpikir dan bernalar, melalui kemampuan penalaran seseorang yang terus dilatih sehingga semakin berkembang, maka orang tersebut akan bertambah daya pikir dan pengetahuannya. Atas dasar inilah Fisika mutlak wajib diajarkan pada setiap peserta didik. Fenomena tersebut merupakan masalah yang serius dan perlu mendapatkan perhatian penuh dari semua pihak, baik pemerintah, sekolah, masyarakat/ orang tua maupun peserta didik itu sendiri. Rendahnya prestasi belajar Fisika peserta didik disebabkan oleh banyak hal antara lain: kurikulum yang padat, materi pada buku pelajaran yang dirasakan terlalu sulit untuk di ikuti, media belajar yang kurang efektif, laboratorium yang tidak memadai, kurang tepatnya penggunaan media pembelajaran yang dipilih oleh guru, kurang optimal dan kurangnya keselarasan peserta didik itu sendiri, atau sifat konvesional, dimana peserta didik tidak banyak terlibat dalam proses pembelajaran dan keaktifan kelas sebagian besar didominasi oleh guru (Supardi dkk,2012: 72)

Dari berbagai faktor penyebab rendahnya prestasi belajar Fisika tersebut, penulis berkecenderungan menyimpulkan bahwa faktor yang menyebabkan rendahnya mutu pembelajaran Fisika disebabkan karena kurangnya kemampuan para guru dalam menanamkan sikap konsep diri dan melihat minat serta kebiasaan belajar peserta didik.

\section{TINJAUAN PUSTAKA \\ Prestasi Belajar Fisika}

Slameto (Astuti \& Leonard, 2012: 104) menyatakan, "belajar adalah suatu proses usaha yang dilakukan seseorang untuk memperoleh suatu perubahan tingkah laku yang baru secara keseluruhan, sebagai hasil pengalamannya sendiri dalam interaksi dengan lingkungannya". Usaha seseorang dalam mencapai sesuatu hal berkaitan dengan usahanya untuk belajar, dengan belajar maka seseorang memperoleh perubahan tingkah laku. Belajar bukan berarti membaca buku pelajaran tetapi belajar yang dimaksud di sini yaitu dari pengalaman kita bisa belajar dari kegagalan.

Tirtarahardja (Astuti \& Leonard, 2012: 104), "belajar adalah perubahan perilaku yang relatif tetap karena pengaruh pengalaman". Menurut pengertian ini, belajar adalah suatu proses kegiatan dan bukan hasil atau tujuan. Belajar tidak hanya mengingat, akan tetapi lebih luas daripada itu, yakni mengalami. Lebih jauh Musfiqon (Astuti \& Leonard, 2012: 105) berpendapat bahwa, "belajar dapat didefinisikan sebuah proses interaksi antara manusia dengan lingkungan yang dilakukan secara terencana untuk mencapai pemahaman, keterampilan, dan sikap yang diinginkan sehingga terjadi perubahan pada diri seseorang dari prestasi belajar tersebut, yaitu kedewasaan diri”. Belajar merupakan aktivitas terencana untuk mendapatkan pengetahuan dan wawasan, agar perilaku seseorang berubah menuju pada kedewasaan. Pemahaman yang telah didapat menjadi sumber nilai yang mempengaruhi seseorang dalam berpikir, bertindak, dan berperilaku.

Belajar merupakan suatu proses internal yang kompleks, belajar merupakan proses internal peserta didik yang tidak dapat diamati secara langsung oleh guru, tetapi dapat dipahami oleh guru melalui perilaku peserta didik yang mempelajari bahan belajar. Menurut Arifin (Astuti \& Leonard, 2012: 105) "Prestasi belajar merupakan suatu masalah yang bersifat perennial dalam sejarah kehidupan manusia, karena sepanjang rentang kehidupannya manusia selalu mengejar prestasi menurut bidang dan kemampuan masingmasing". Dari teori di atas maka pengertian prestasi belajar itu adalah ilmu pengetahuan yang diperoleh dalam proses belajar yang dihasilkan dari tes beberapa bidang studi sehingga mendapatkan hasil/skor.

Betapa pentingnya seorang pengajar mengetahui dan memahami prestasi belajar peserta didik, baik secara perseorangan maupun secara kelompok, sebab fungsi prestasi 
belajar tidak hanya sebagai indikator keberhasilan dalam bidang studi tertentu, tetapi juga sebagai indikator kualitas institusi pendidikan. Arifin (Astuti \& Leonard, 2012: 105) berpendapat lain bahwa "Prestasi belajar juga bermanfaat sebagai umpan balik bagi guru dalam melaksanakan proses pembelajaran sehingga dapat menentukan apakah perlu melakukan diagnosis, penempatan, atau bimbingan terhadap peserta didik". Hasil penilaian dari evaluasi merupakan umpan balik untuk mengukur sampai dimana keberhasilan proses belajar mengajar. Dengan nilai-nilai yang diperoleh peserta didik, guru pun akan mengetahui sejauh mana keberhasilannya dalam mengajar, dan hal itu dapat digunakan untuk perbaikan dalam proses pembelajaran berikutnya.

Menurut Kanginan (2004: 1) "Fisika adalah ilmu pengetahuan yang mempelajari gejala-gejala alam dan interaksi gejala-gejala alam itu. Di dalam Fisika, kita mempelajari gejala-gejala alam, baik yang terjadi pada benda-benda atau materi yang dapat kita amati (makro) maupun benda-benda yang tidak dapat kita amati (mikro)".

Pelajaran Fisika di sekolah di harapkan dapat menjadi wahana bagi peserta didik untuk mempelajari diri sendiri dan alam sekitarnya, serta prospek pengembangan lebih lanjut yang dapat diterapkan dalam kehidupan sehari-hari. Pembelajaran yang menekankan pada pengalaman langsung untuk mengembangkan kompetensi agar peserta didik mampu memahami alam sekitar melalui "mencari tahu" dan "berbuat", sehingga membantu peserta didik untuk memperoleh pemahaman yang lebih mendalam (Puskur (Supardi dkk, 2012: 74).

Keterampilan untuk mencari tahu atau berbuat dalam Fisika disebut keterampilan proses penyelidikan atau "enquary skills" yang meliputi mengamati, mengukur, menggolongkan, mengajukan pertanyaan, menyusun hipotesis, merencanakan eksperimen untuk menjawab pertanyaan, mengklasifikasikan, mengolah, dan menganalisis data, menerapkan ide pada situasi baru, menggunakan peralatan sederhana serta mengkomunikasikan informasi dalam berbagai cara, yaitu dengan gambar, lisan, tulisan, dan sebagainya (Harlen (Supardi dkk,2012: 74).

Melalui keterampilan proses dikembangkan sikap dan nilai yang meliputi rasa ingin tahu, jujur, sabar, terbuka, tidak percaya tahayul, kritis, tekun, ulet, cermat, disiplin, peduli terhadap lingkungan, memperhatikan keselamatan kerja, dan bekerja sama dengan orang lain (Harlen (Supardi dkk ,2012: 74)

Dari definisi diatas dapat diartikan bahwa fisika adalah ilmu yang mempelajari perilaku dan sifat materi dalam bidang yang sangat beragam, mulai dari partikel submikroskopis yang membentuk segala materi (Fisika partikel) hingga perilaku materi alam semesta sebagai satu kesatuan. Fisika merupakan ilmu pengetahuan yang mempelajari gejala-gejala alam (benda-benda) baik secara mikro maupun makro dan interaksinya dan berusaha untuk menemukan hubungan-hubungan antara gejala-gejala tersebut dengan kenyataan yang ada.

Berdasarkan definisi diatas prestasi belajar Fisika adalah: 1) proses memberikan pengalaman pada peserta Didik sehingga mereka kompeten melakukan pengukuranpengukuran besaran fisis. Semua konsep yang dipelajari dalam Fisika harus dapat diamati, dapat diukur dengan alat, sehingga esensi pengukuran hendaknya tertanam dengan kuat dalam diri peserta didik, 2) dapat menanamkan pentingnya pengamatan empiris dalam menguji suatu pernyataan ilmiah (hipotesis). Hipotesis ini dapat berasal dari pengamatan terhadap kejadian sehari-hari yang memerlukan verifikasi ilmiah, 3) sebagai latihan berfikir kuantitatif mendukung kegiatan belajar Fisika, yaitu sebagai penerapan Fisika pada masalah-masalah nyata yang berkaitan dengan peristiwa alam, 4) memperkenalkan dunia teknologi melalui kegiatan kreatif perancangan dan pembuatan alat-alat sederhana maupun penjelasan berbagai gejala Fisika dan keampuhan Fisika 
dalam menjawab berbagai masalah. Dengan demikian peserta didik akan melihat dengan nyata manfaat Fisika, sehingga membuat Fisika menarik bagi peserta didik.

\section{Konsep Diri}

Konsep diri merupakan tanggapan individu yang sehat terhadap diri dan kehidupannya. Konsep diri juga merupakan landasan dasar untuk dapat menyesuaikan diri. Dengan kata lain, konsep diri merupakan hal yang sangat mempengaruhi penyesuaian diri dan merupakan faktor penting dalam perkembangan diri seseorang. Konsep diri bukan merupakan faktor yang dibawa sejak lahir, melainkan faktor yang dijiwai dan terbentuk melalui pengalaman individu dalam berhubungan dengan orang lain. Dalam berinteraksi ini setiap individu akan menerima tanggapan. Tanggapan yang diterima tersebut akan dijadikan cermin bagi individu untuk menilai dan memandang dirinya sendiri. Jadi konsep diri terbentuk karena suatu proses umpan balik dari individu lain (Leonard \& Supardi, 2010: 343).

Menurut Elizabeth Hurlock (Leonard \& Supardi,2010: 343), konsep diri adalah gambaran yang dimiliki orang tentang dirinya". Lebih lanjut lagi Burn (Leonard \& Supardi,2010: 343), mengatakan bahwa konsep diri adalah "gambaran campuran dari apa yang kita pikirkan, orang-orang berpendapat mengenai diri kita, dan seperti apa diri kita yang kita inginkan". Konsep diri meliputi apa yang seseorang pikirkan dan rasakan tentang dirinya. Solomon (Leonard \& Supardi, 2010: 343), berpendapat bahwa: "The self-concept refers to the beliefs aperson holds about his or her own attributes, and how he or she evaluates these qualities. Although one's overall selfconcept may be positive, there certainly are parts of the self that are evaluated more positively than other". Adanya struktur, peran dan status sosial yang menyertai seluruh perilaku individu dipengaruhi oleh faktor sosial. Adanya pengaruh faktor sosial terhadap perkembangan konsep diri individu telah dibuktikan oleh Rosenberg (Pudjijogyanti (Leonard \& Supardi, 2010: 343). Dijelaskan bahwa perkembangan konsep diri tidak terlepas dari pengaruh faktor sosial, agama, ras. Dijelaskan bahwa individu yang berstatus sosial yang tinggi akan mempunyai konsep diri yang lebih positif dibandingkan individu yang berstatus sosial rendah. Individu dewasa mengalami kesulitan untuk menggabungkan diri dengan satu kelompok sosial tertentu yang cocok dengan dirinya. Salah satu tugas perkembangan yang harus dilakukan oleh individu dewasa adalah menjadi bagian dari satu kelompok sosial tertentu. Berdasarkan paparan di atas, maka penulis merasa perlu untuk meneliti, dengan tujuan untuk menemukan secara empiris tentang peran variabel konsep diri, minat dan kebiasaaan belajar terhadap prestasi belajar fisika.

\section{Minat Belajar}

Arti minat menurut Slameto (2010: 180) adalah suatu rasa lebih suka dan rasa ketertarikan pada suatu hal atau aktivitas, tanpa ada yang menyuruh. Minat pada dasarnya adalah penerimaan akan suatu hubungan antara diri sendiri dengan sesuatu diluar diri. Semakin kuat atau dekat hubungan tersebut, semakin besar minat.

Beberapa ahli pendidikan berpendapat bahwa cara yang paling efektif untuk membengkitkan minat pada suatu subyek yang baru adalah dengan menggunakan minatminat peserta didik yang telah ada. Disamping memanfaatkan minat yang telah ada, Tabrani (Supardi dkk, 2012: 75) menyarankan agar para pengajar juga berusaha membentuk minat-minat baru pada diri peserta didik dalam belajar. Hal ini dapat dicapai dengan jalan memberikan informasi pada peserta didik mengenai hubungan antara suatu bahan pengajaran yang akan diberikan dengan bahan pengajaran yang lalu, menguraikan kegunaannya bagi peserta didik dimasa yang akan datang. Rooijakkers (Supardi dkk, 2012: 75) berpendapat hal ini dapat pula dicapai dengan cara menghubungkan bahan 
pengajaran dengan suatu berita sensasional yang sudah diketahui banyak peserta didik, misalnya, akan menaruh perhatian pada pelajaran tentang gaya berat bila hal itu dikaitkan dengan peristiwa mendaratnya manusia pertama di bulan.Bila usaha-usaha di atas tidak berhasil, guru dapat memakai insentif dalam usaha mencapai tujuan pengajaran. Insentif merupakan alat yang dapat digunakan untuk membujuk seseorang agar melakukan sesuatu yang tidak mau melakukannya atau yang tidak dilakukannya dengan baik. Diharapkan pemberian insentif akan membangkitkan motivasi peserta didik dan mungkin minat terhadap bahan yang diajarkan akan muncul. Menurut Slameto dalam Wilson (Supardi dkk, 2012: 75) menyatakan bahwa minat belajar adalah rasa suka ketertarikan padasuatu pelajaran atau aktivitas tanpa ada yang menyuruh, minat pada hakekatnya adalah penerimaan hubungan antara diri sendiri dengan sesuatu diluar dirinya, semakin kuat atau semakin dekat hubungan tersebut maka semakin besar minatnya.

Dari beberapa pendapat tersebut dapat ditemukan adanya beberapa unsur pokok dalam pengertian minat belajar yaitu adanya perhatian, daya dorong tiap-tiap individu untuk belajar dan kesenangan yang dapat menjadikan minat belajar itu timbul pada diri seseorang. Jadi minat belajar adalah sesuatu keinginan atau kemauan yang disertai perhatian dan keaktifan yang disengaja yang akhirnya melahirkan rasa senang dalam perubahan tingkah laku, baik berupa pengetahuan, sikap maupun ketrampilan. Minat merupakan salah satu faktor yang dapat mempengaruhi usaha yang dilakukan seseorang. Minat yang kuat akan menimbulkan usaha yang gigih, serius dan tidak mudah putus asa dalam menghadapi tantangan. Jika seorang peserta didik memiliki rasa ingin belajar, ia akan cepat dapat mengerti dan mengingatnya. Dalam hubungannya dengan pemusatan perhatian, minat mempunyai peranan dalam " melahirkan perhatian yang serta merta, memudahkan terciptanya pemusatan perhatian dan mencegah gangguan perhatian dari luar". Oleh karena itu minat mempunyai pengaruh yang besar dalam belajar karena bila bahan pelajaran tidak sesuai dengan minat peserta didik, maka peserta didik tersebut tidak akan belajar dengan sebaik-baiknya sebab tidak ada daya tarik baginya.

\section{Kebiasaan Belajar}

Muhibbin Syah (Sukarno, 2009: 61) menyatakan bahwa kebiasaan merupakan bentuk tingkah laku yang menetapkan yang timbul karena adanya penyusutan kecenderungan respon dengan menggunakan stimulus berulang-ulang. Tindakan belajar yang dilakukan secara berulang-ulang pada akhirnya akan bersifat monoton, pada akhirnya akan berubah menjadi sebuah kebiasaan. Kebiasaan yang telah lama tertanam akan sulit dirubah atau diperbaharui, untuk itu perlu adanya pengarahan dari guru atau orang tua supaya peserta didik dapat membangun kebiasaan belajar positif.

Moh.Surya (Sukarno, 2009: 54) menyatakan bahwa kebiasaan adalah suatu cara individu untuk suatu masa tertentu, tingkah laku yang menjadi kebiasaan tidak memerlukan fungsi berpikir yang cukup tinggi karena sifatnya sudah relatif menetap.

Berdasarkan pengertian tersebut juga dijelaskan bahwa kebiasaan adalah kegiatan yang dilakukan secara berulang-ulang sehingga kegiatan tersebut bersifat spontan. Pembiasaan berlangsung berkat adanya pengulangan dan pelatihan yang berkelanjutan.Setiap individu memiliki kebiasaan yang berbeda dalam belajar, kebiasaan dibangun oleh setiap pribadi peserta didik. Hanya saja tidak semua kebiasaan belajar bersifat positif dan mendukung pencapaian tujuan belajar. Kebiasaan belajar yang dibangun secara bebas oleh peserta didik sering mengarah pada posisi yang kurang layak. Sebaliknya kebiasaan belajar yang dibangun dengan kekerasan dan tekanan yang berlebihan sering menimbulkan gejolak dan penolakan dari peserta didik. Dalam hal ini dibutuhkan kebebasan dan bimbingan dari guru agar peserta didik dapat membangun 
kebiasaan belajar positif, sehingga mampu mendukung tindakannya untuk menguasai materi pelajaran yang telah disampaikan.

\section{METODE}

Metode Penelitian ini menggunakan metode analisis kuantitatif. Responden atau sampel diambil dari 3 SMA Negeri di Wilayah Depok Propinsi Jawa Barat. Jenis data yang digunakan dalam penelitian ini adalah data primer berupa data peserta didik dan nilai yang diperoleh penulis secara langsung database SMA Negeri di Wilayah Depok Propinsi Jawa Barat. Desain penelitian yang digunakan adalah desain korelasional, yaitu korelasi dan regresi ganda.

Populasi target dalam penelitian ini adalah seluruh peserta didik SMA Negeri di wilayah Depok, Jawa Barat tahun pelajaran 2011/2012. yang berjumlah 8 sekolah, Yaitu SMA Negeri 1 Depok, SMA Negeri 2 Depok, SMA Negeri 3 Depok, SMA Negeri 4 Depok, SMA Negeri 5 Depok, SMA Negeri 6 Depok, SMA Negeri 7 Depok dan SMA Negeri 8 Depok. Sebagai populasi terjangkau dalam penelitian ini adalah peserta didik kelas X SMA Negeri di wilayah Depok, Jawa Barat tahun pelajaran 2011/2012. Dimana yang ditetapkan sebagai sampel sebanyak 100 peserta didik dari 3 SMA yaitu SMA 6 Depok, SMA 5 Depok dan SMA 8 Depok

Analisis data menggunakan teknik analisis deskriprif untuk mencari harga rata-rata, simpangan baku, distribusi frekuensi, modus, mean, median, pembuatan histogram dari skor Y (prestasi belajar fisika peserta didik), skor $\mathrm{X}_{1}$ (konsep diri), skor $\mathrm{X}_{2}$ (minat) dan dan skor $\mathrm{X}_{3}$ (kebiasaan belajar). Uji Persyaratan Analisis Data yang digunakan adalah Uji Normalitas dan Uji Linieritas. Teknik pengujian hipotesis yang digunakan adalah korelasi dan regresi ganda.

\section{HASIL DAN PEMBAHASAN}

Data Prestasi Belajar Matematika

Dari hasil pengukuran prestasi belajar fisika terhadap 100 peserta didik yang dijadikan sampel penelitian, diperoleh data skor maksimum 86,67 dan skor minimum 20,00. Berdasarkan hasil analisis data, diperoleh mean 56,65; median 54,67; modus 59,00; dan simpangan baku 16,98.

\section{Data Konsep Diri}

Dari hasil pengukuran prestasi belajar fisika terhadap 100 peserta didik yang dijadikan sampel penelitian, diperoleh data skor maksimum 175 dan skor minimum 108 . Berdasarkan hasil analisis data, diperoleh mean 143,63; median 143; modus 142; dan simpangan baku 14,47.

\section{Data Minat Belajar}

Dari hasil pengukuran prestasi belajar fisika terhadap 100 peserta didik yang dijadikan sampel penelitian, diperoleh data skor maksimum 170 dan skor minimum 101. Berdasarkan hasil analisis data, diperoleh mean 136,31; median 137; modus 137; dan simpangan baku 15,58.

\section{Data Kebiasaan Belajar}

Dari hasil pengukuran prestasi belajar fisika terhadap 100 peserta didik yang dijadikan sampel penelitian, diperoleh data skor maksimum 174 dan skor minimum 108. Berdasarkan hasil analisis data, diperoleh mean 141,92; median 142; modus 145; dan simpangan baku 15,65. 


\section{Uji Persyaratan Analisis Data}

Data yang telah dikumpulkan selanjutnya diuji persyaratan analisis, yang meliputi uji normalitas dan uji linieritas. Hasil pengujian normalitas menggunakan menggunakan uji kolmogorof-smirnov diperoleh hasil bahwa seluruh variabel berdistribusi normal. Hasil pengujian linieritas menggunakan tabel bantuan ANAVA diperoleh hasil bahwa persamaan regresi yang terbentuk antara kedua variabel adalah linier, sehingga dapat dilanjutkan menggunakan statistik parametrik, dengan uji korelasi dan regresi linier berganda.

\section{Pengujian Hipotesis Penelitian}

Konsep diri peserta didik, minat belajar peserta didik dan kebiasaan belajar peserta didik memberikan pengaruh terhadap prestasi belajar Fisika peserta didik yang ditandai dengan perolehan koefesien korelasi ganda $\left(r_{y 123}\right)$ sebesar 0,948 lebih dari $r_{\text {tabel }}$ sebesar 0, 195 mempunyai makna bahwa pengaruh antara konsep diri peserta didik, minat belajar peserta didik dan kebiasaan belajar peserta didik terhadap prestasi belajar Fisika peserta didik sangat kuat. Sementara itu hasil koefisien determinasi ganda $\left(\mathrm{r}_{\mathrm{y} 123}^{2}\right)$ sebesar $=0,898$ mempunyai makna bahwa 89,8\% yang terjadi dalam kecenderungan besarnya pengaruh meningkatnya konsep diri peserta didik, minat belajar peserta didik dan kebiasaan belajar peserta didik terhadap prestasi belajar Fisika peserta didik. Sisanya 10,2 \% dipengaruhi oleh sebab-sebab lain. Persamaan regresi $\hat{Y}=-97,138+0,546 X_{1}+0,333$ $\mathrm{X}_{2}+0,211 \mathrm{X}_{3}$. Yang berarti bahwa kenaikan satu skor konsep diri peserta didik, minat belajar peserta didik dan kebiasaan belajar peserta didik akan memberikan kenaikan sebesar 0,546 untuk variabel $X_{1}, 0,333$ untuk variabel $X_{2}$ dan 0,211 untuk variable $X_{3}$ terhadap skor prestasi belajar Fisika peserta didik. Uji signifikasi regresi menunjukkan $F_{\text {hitung }}=281,728$ lebih besar dari $\mathrm{F}_{\text {tabel }} 2,70$

\section{Pembahasan Hasil Penelitian}

\section{Pengaruh Konsep Diri Terhadap Prestasi Belajar Fisika}

Hasil pengolahan memberikan hasil signifikan, yang artinya ada pengaruh positif yang berarti antara konsep diri terhadap prestasi belajar fisika. Hal ini kembali menegaskan hasil penelitian sebelumnya, yaitu konsep diri memberikan kontribusi berarti bagi variabel prestasi belajar fisika. Konsep diri merupakan cara pandang peserta didik terhadap dirinya sendiri meliputi faktor-faktor yang berhubungan dengan citra diri dan pemahaman seseorang tentang dirinya. Seseorang dengan konsep diri tinggi memiliki pemahaman yang baik tentang kemampuan dan kompetensi yang dimilikinya, memiliki citra diri dan kepercayaan diri yang baik, sehingga berdampak pada cara belajar dan melakukan aktivitas sebagai seorang pelajar. Hasil ini diartikan bahwa semakin tinggi konsep diri seseorang maka akan semakin tinggi pula prestasi belajarnya, sebaliknya semakin rendah konsep diri seseorang maka akan semakin rendah pula prestasi belajarnya.

\section{Pengaruh Minat Belajar Terhadap Prestasi Belajar Fisika}

Hasil pengolahan memberikan hasil signifikan, yang artinya ada pengaruh positif yang berarti antara minat belajar terhadap prestasi belajar fisika. Hal ini kembali menegaskan hasil penelitian sebelumnya, yaitu minat belajar memberikan kontribusi berarti bagi variabel prestasi belajar fisika. Minat adalah suatu rasa lebih suka dan rasa ketertarikan pada suatu hal atau aktivitas, tanpa ada yang menyuruh. Seeorang dengan minat belajar yang tinggi akan menjadikan dia memiliki rasa lebih senang dalam diri seseorang dalam memberikan perhatian yang lebih besar terhadap objek tertentu. Hasil ini diartikan bahwa semakin tinggi minat belajar seseorang maka akan semakin tinggi pula prestasi 
belajarnya, sebaliknya semakin rendah minat belajar seseorang maka akan semakin rendah pula prestasi belajarnya

\section{Pengaruh Kebiasaan Belajar Terhadap Prestasi Belajar Fisika}

Hasil pengolahan memberikan hasil tidak signifikan, yang artinya tidak ada pengaruh positif yang berarti antara kebiasaan belajar terhadap prestasi belajar fisika. Hal ini kembali menegaskan hasil penelitian sebelumnya, yaitu kebiasaan belajar tidak memberikan kontribusi berarti bagi variabel prestasi belajar fisika. Kebiasaan belajar adalah suatu cara individu untuk bertindak, bertingkah laku akibat dari proses berulangulang dengan sifat yang relatif menetap sebagai usaha untuk menyesuaikan diri terhadap lingkungan. Selanjutnya kebiasaan belajar harus dikembangkan melalui kesadaran akan manfaat belajar dan kesadaran akan tanggung jawab untuk menguasai materi pelajaran yang telah disampaikan guru maupun tanggung jawab menyelesaikan tugas sekolah.

Hasil ini diartikan bahwa belum tentu semakin tinggi kebiasaan belajar seseorang maka akan semakin tinggi pula prestasi belajarnya, atau belum tentu semakin rendah kebiasaan belajar seseorang maka akan semakin rendah pula prestasi belajarnya

\section{Pengaruh Konsep Diri, Minat Belajar dan Prestasi Belajar secara bersama-sama Terhadap Prestasi Belajar Fisika}

Hasil pengolahan memberikan hasil yang signifikan yang artinya ada pengaruh konsep diri, minat dan kebiasaan belajar secara bersama-sama terhadap prestasi belajar fisika. Fakta ini memberikan pemahaman baru bahwa ketiga variabel ini secara sinergi dapat memunculkan performa terbaik peserta didik, yaitu dengan memiliki konsep diri, minat dan kebiasaan belajar yang baik seseorang peserta didik akan mampu mendapatkan prestasi belajar yang baik pula.

\section{PENUTUP}

\section{Simpulan}

Secara keseluruhan penelitian ini menemukan bahwa terdapat pengaruh positif antara konsep diri, minat dan kebiasaan belajar secara bersama-sama terhadap prestasi belajar fisika. Secara individual, ditemukan bahwa terdapat pengaruh positif antara konsep diri terhadap prestasi belajar fisika, dan terdapat pengaruh positif antara minat belajar terhadap prestasi belajar fisika. Akan tetapi, sebaliknya tidak ditemukan pengaruh positif antara kebiasaan belajar terhadap prestasi belajar fisika.

\section{Saran/Rekomendasi}

Dari temuan di atas maka dapat disarankan beberapa hal, yaitu: 1) Guru dan satuan pendidikan seharusnya berusaha menanamkan konsep diri yang benar kepada peserta didik, hal ini dapat dilakukan dengan banyak hal seperti pemberian kepercayaan kepada peserta didik untuk memegang tanggung jawab tertentu, rasa percaya diri peserta didik dalam belajar dan dalam menghadapi berbagai persoalan karena pemberian kepercayaan dan penanaman rasa kepercayaan diri ini dapat membantu peserta didik dalam meningkatkan prestasinya dalam belajar. 2) guru dan satuan pendidikan hendaknya dapat memberikan dorongan kepada peserta didik untuk dapat meningkatkan prestasinya dalam belajar. Dorongan ini bisa bersifat internal maupun eksternal. Dorongan internal yang dimaksud adalah dengan meningkatkan rasa percaya diri peserta didik dalam menghadapi berbagai persoalan yang dihadapinya, sementara itu, dorongan eksternal adalah dengan memberikan penghargaan bagi yang berprestasi dalam pembelajaran. 3) Untuk meningkatkan prestasi belajar Fisika guru hendaknya dapat menarik minat peserta didik dalam belajar Fisika dengan berbagai cara agar peserta didiknya mau berkonsentrasi, 
memahami dan melatih kemampuan terhadap materi yang diberikan dan menghilangkan paradigma lama yakni guru fisika selalu terkesan menakutkan.

\section{DAFTAR PUSTAKA}

Marthin Kanginan. 2004. Fisika 1A SMU. Jakarta: Erlangga

Muhibbin Syah. 1997. Psikologi Pendidikan dengan Pendekatan Baru. Bandung: Rosdakarya

Slameto, 2010. Belajar dan Faktor-Faktor Yang Mempengaruhinya. Jakarta: Rineka cipta.

Sugiyono. 2007. Statistik Untuk Penelitian. Bandung: Alfabeta

Supardi, U.S. 2013. Aplikasi Statistika Dalam Penelitian. Jakarta: PT.Prima Ufuk Semesta

Surya, Moh. 1992. Psikologi Pendidikan. Bandung: Remaja Rosda Karya.

Astuti \& Leonard. 2012. Peran kemampuan komunikasi matematika terhadap prestasi belajar matematika peserta didik. Jurnal Formatif, 2 (2): 104-105.

Leonard \& Supardi. 2010. Pengaruh konsep diri, sikap peserta didik pada matematika, dan kecemasan peserta didik terhadap prestasi belajar matematika. Cakrawala Pendidikan. 29 (3): 343.

Supardi, dkk. 2012. Pengaruh media pembelajaran dan minat belajar terhadap prestasi belajar fisika. Jurnal Formatif, 2 (1): 71-81. 